\title{
Effect of the type of egg yolk, removal of seminal plasma and donor age on ram sperm cryopreservation
}

\author{
Wilber García ${ }^{1}$, Abigail Tabarez ${ }^{1,2}$, Maria Jesus Palomo ${ }^{1,3}$ \\ ${ }^{1}$ Department of Animal Medicine and Surgery, Universitat Autònoma de Barcelona, Bellaterra, Spain. \\ ${ }^{2}$ Faculty of Biological and Agricultural Sciences. University Veracruzana. Tuxpan, Veracruz, Mexico.
}

\begin{abstract}
This study was conducted to assess the effect on ram sperm freezability by the replacement of traditional fresh egg yolk (FEY) with fresh clarified egg yolk (CEY) or powdered egg yolk (PEY) in extenders. Simultaneously, the effect of semen washing and donor age ( 1 and 2 years old) was studied on thawed sperm quality. Briefly, in two consecutives autumns, ejaculates from 8 males were collected by artificial vagina, mixed and split into two samples. One sample was washed by centrifugation and the pellet was split into three aliquots and re-suspended in an extender containing $15 \%$ of different type of egg yolk (PEY, FEY or CEY) supplemented with 5\% glycerol in a Tris-based medium. The other sample was directly split into three aliquots and diluted in the same extenders. All samples were chilled for $4 \mathrm{~h}$ at $5^{\circ} \mathrm{C}$ before been frozen to $-196^{\circ} \mathrm{C}$. The results suggested that powdered egg yolk can be used satisfactory on ram sperm cryopreservation ensuring greater bio-security meanwhile fresh clarified egg yolk did not improve sperm freezability. Moreover, semen from 2 years old donors was more resistant to cryopreservation than semen collected from younger males. Finally, sperm washing had a beneficial effect on sperm cryosurvival.
\end{abstract}

Keywords: age, cryopreservation, egg yolk, ram sperm, seminal plasma.

\section{Introduction}

In the last 60 years, fresh egg yolk has been included in most of semen cryopreservation protocols in domestic and wild species. The exact mechanism how egg yolk helps to preserve spermatozoa during freezingthawing process is still unknown (Salamon and Maxwell, 2000), although its cryoprotectant action has been conferred mainly to their low density lipoproteins (LDL) (Watson and Martin, 1975; Moussa et al., 2002). Several works have been published about the possibility of using more efficient egg yolk as a non-penetrating cryoprotectant on semen extenders with complex LDL extraction and purification methods (Pace and Graham, 1974; Moussa et al., 2002). However, an easier and quicker manner to separate both main egg yolk fractions (plasma and granules) has been also described by increasing LDL content through a simple centrifugation process. This clarified egg yolk or plasma is mainly composed of LDL (85\%) and livetelins (15\%) (Anton et al., 2003).
Nevertheless, the use of clarified or fresh egg yolk in sperm cryopreservation media represents a potential risk of microbiological contamination in artificial insemination doses, damaging the fertility of the spermatozoa (Bousseau et al., 1998). Moreover, fresh egg yolk is very complex product in which its composition can be extremely variable and different among lots (Kampschmidt et al., 1953; Watson and Martin, 1975), thus the search for an egg yolk substitute is highly desirable. Powdered egg yolk could be an alternative to fresh egg yolk due to the pasteurization process to destroy bacteria (Thibier and Guerin, 2000) with a higher homogeneous composition. However, very few research on its use for sperm cryopreservation has been done.

On the other hand, seminal plasma is the natural medium where sperm are found after ejaculation, which supports their transport and metabolism, giving them protection and controlling several processes such as motility, capacitation and the recognition and union between gametes (Maxwell et al., 2007). During ram sperm cryopreservation, seminal plasma seems to increase sperm resistance to cold shock (Barrios et al., 2000; 2005), reducing cryocapacitation process which seriously limits the life of the spermatozoa and consequently their fertilization capacity. However, negative effects of the presence of seminal plasma in the cryopreservation process have also been reported (Maxwell et al., 2007), and frequently in goat semen (Aboagla and Terada, 2003). Nevertheless, Bergeron et al. (2004) suggested that the egg yolk in extender protects sperm by preventing BSP (bovine seminal plasma) proteins in seminal plasma to bind to sperm which intrinsically damage sperm membrane by removing lipid. Therefore, the necessity to eliminate the seminal plasma or not in ram sperm cryopreservation is still a study issue.

Also, it is worthy to remember that semen production, and consequently, their reproductive potential progresses according the age of the male. Therefore, adult rams show higher semen quality and fertility than young males (Folch, 1984; Beltrán de Heredia 2009), in relation to the development of sexual maturity. Likewise, the increase of the testicular volume, annexe glandules and protein concentration in seminal plasma observed while rams are growing had an effect in quality and fertility of refrigerated and cryopreserved spermatozoa, being higher in adult animals (Colas and Zinsner, 1975; Rodríguez-Almeida et al., 2008). Therefore, the main objective of the present study was to assess the effect of different egg 
yolk types (fresh, fresh clarified and powdered) on viability, motility, acrosome status, mitochondrial function and morphometry of the spermatozoa after cryopreservation. Also, the effect of seminal plasma elimination and the donor age was taken in consideration.

\section{Material and Methods}

All chemicals and reagents were purchased from Sigma Chemical Co. (St. Louis, Mo, USA) unless otherwise stated. The powdered egg yolk was obtained from NIVE (Nunspeet Holland Eiproducten).

\section{Semen Extenders}

The basic extender used in this study was Tris (hydroxymethyl-aminoethane)-citric acid-glucose (TCG) solution as defined by Salamon and Maxwell (2000), consisting of Tris $(0.3 \mathrm{M})$, citric acid anhydrous (94.7 $\mathrm{mM})$, and $\mathrm{D}(+)$-glucose $(27.75 \mathrm{mM})$. This solution was adjusted to a $\mathrm{pH}$ of $7.25 \pm 0.05$ and the osmolarity to $333.0 \pm 2.8 \mathrm{mOsm}$. Thereafter, glycerol $(5 \% \mathrm{v} / \mathrm{v}$, final concentration) and antibiotics (1000 UI/mL sodium penicillin and $1,0 \mathrm{mg} / \mathrm{mL}$ streptomycin sulfate) were added to the solution having a final $\mathrm{pH}$ of 7.0-7.17 and an osmolarity of $1327 \pm 234 \mathrm{mOsm}$. Afterwards, fresh (FEY), clarified (CEY) or powdered (PEY) egg yolk were added to the extender at a final concentration of $15 \%$.

To obtain the two different types of egg yolk (FEY and CEY), fresh eggs were collected from farm hens (24-48 h maximum after egg laying). Then, eggs were manually broken and yolks were separated from the albumen. Each yolk was carefully rolled on a filter paper to remove chalazae and traces of albumen adhering to the vitelline membrane. The vitelline membrane was then disrupted with a scalpel blade and yolk was collected with the aid of a syringe. To obtain the clarified egg yolk (CEY), plasma was fractionated from the yolk according the method described by Holt et al. (1996). Yolk was diluted (1:2) with Milli Q water in an eppendorf tube and centrifuged at $10,000 \mathrm{~g}$, for 45 minutes at $5^{\circ} \mathrm{C}$. Then, the supernatant (plasma) was carefully recuperated avoiding any contamination from the sediment (granules). This supernatant was centrifuged again at $10,000 \mathrm{~g}$, for 45 minutes at $5^{\circ} \mathrm{C}$. After centrifuging twice, the supernatant was considered as the clarified egg yolk or plasma. Preparation of the powdered egg yolk was done according the method described by Marco-Jiménez et al. (2004). Briefly, powdered egg yolk (NIVE, Nunspeet Holland Eiproducten) was diluted (1:1.25) with Milli Q water, and stirred for $20 \mathrm{~min}$

\section{Semen collection and freezing protocols}

Semen was collected twice weekly with two ejaculates per collection from each male, with the aid of an artificial vagina on eight rams (4 of Xisqueta and 4 of Aranesa breed) in two consecutive negative photoperiods at one and two years old. After collection, all ejaculates were mixed together and divided into two equal samples. One sample was washed twice by dilution (1:5) in TGC and centrifuged at $600 \mathrm{X}$ g for 10 min. Thereafter, the supernatant was carefully removed and the resulting sediment was divided into three equal aliquots and re-suspended in an extender containing egg yolk concentration of $15 \%(\mathrm{v} / \mathrm{v})$ of the different types of egg yolk (PEY, FEY or CEY) used in this study. The other sample (non-washed) was divided into three equal aliquots and diluted in the same extenders with different type of egg yolk (powdered, fresh or clarified). All samples were then chilled for 4 hours at $5^{\circ} \mathrm{C}$ before freezing. Sperm were then packaged at a final concentration of $400 \times 10^{6}$ sperm $/ \mathrm{mL}$ in $0.25 \mathrm{~mL}$ straws (IMV Technologies, L'Aigle, Cedex, France) and sealed with polyvinyl alcohol. Straws were frozen in liquid nitrogen vapors for $10 \mathrm{~min}, 5 \mathrm{~cm}$ above the nitrogen level and later plunged into the liquid nitrogen for storage.

\section{Fresh and thawed sperm evaluation}

The volume and mass motility of the mixture of fresh ram ejaculates from animals of one and two years old, respectively were registered. Fresh sperm viability was estimated by eosine/nigrosine $(\mathrm{E} / \mathrm{N})$ vital staining (Hancock, 1951) as well as the analysis of the functionality of the plasma membrane by hypoosmotic swelling test (HOS test). This test consisted of incubation $20 \mu \mathrm{L}$ of sperm suspension in $180 \mu \mathrm{L}$ of hypotonic solution $(100 \mathrm{mOsm})$ at $37^{\circ} \mathrm{C}$ for 30 minutes (Forouzanfar et al., 2010). After incubation 2 smears/sample were performed by placing $10 \mu \mathrm{L}$ of sample and $10 \mu \mathrm{L}$ of eosine-nigrosine for observation in the optical microscope at X 1000 .

After cryopreservation process, two straws from each treatment were thawed in every replicate by immersion in a water bath at $37^{\circ} \mathrm{C}$ for 30 seconds and the content poured in a dry tube kept at the same temperature for analysis.

\section{Motion parameters}

Sperm motility parameters were assessed using the computer-assisted sperm analysis (CASA) system ISAS ${ }^{\circledR}$ (PROISER SL., Valencia, Spain). An aliquot of frozen/thawed sperm was diluted (1:100) in PBS, and a $10 \mu \mathrm{L}$ drop of sperm suspension was placed onto a slide and covered with a coverslip $(24 \times 24 \mathrm{~mm})$. Sperm motility was assessed at $38^{\circ} \mathrm{C}$ at $\mathrm{X} 200$ using a phase contrast microscope (Olympus BH-2, Japan). For each sample, more than three fields per drop were analyzed and a minimum of 200 sperm evaluated. The percentage of total motile sperm cells (\%), progressive motility $(\%)$, curvilinear velocity $(\mathrm{VCL}, \mu \mathrm{m} / \mathrm{s})$, linear velocity (VSL, $\mu \mathrm{m} / \mathrm{s}$ ), mean velocity (VAP, $\mu \mathrm{m} / \mathrm{s}$ ), linearity coefficient $(\mathrm{LIN}=[\mathrm{VSL} / \mathrm{VCL}] \times 100, \%)$, straightness coefficient $(\mathrm{STR}=[\mathrm{VSL} / \mathrm{VAP}] \times 100, \%)$, lateral head displacement (ALH, $\mu \mathrm{m})$ and beat cross frequency (BCF, Hz) were evaluated. The settings used for the sperm image analyses were as follows: number of images (25/s), optical (Ph-), scale (20xOlympus), 
particle area $\left(>3 \mathrm{a}<70 \mu \mathrm{m}^{2}\right)$, slow sperm $(10-45 \mu \mathrm{m} / \mathrm{s})$, average sperm $(45-75 \mu \mathrm{m} / \mathrm{s})$, rapid sperm $(>75 \mu \mathrm{m} / \mathrm{s})$, progressive ( $80 \% \mathrm{STR})$.

\section{Morphometric analysis of sperm heads}

Microscope slides were prepared from each diluted sample of frozen/thawed sperm (upon dilution 1:100 in PBS) by placing $10 \mu \mathrm{L}$ of the sperm samples on the clear end of a frosted slide and dragging the drop across the slide. Semen smears were air-dried and stained using a Diff- Quick ${ }^{\circledR}$ procedure. Stained slides analyses were used to perform automated sperm morphometric analysis (ASMA) using the morphometry module of CASA system ISAS ${ }^{\circledR}$. The equipment was an Olympus BH-2 microscope with X 60 bright-field objective and a video camera (Basler A312f, Germany), connected to a PC (DELL Intel Core Duo, Windows 7). Resolution of images was $0.137615 \mu \mathrm{m}$ per pixel in the horizontal and vertical axes. A green filter (Olympus If 550, Tokyo, Japan) was used, to increase the contrast thereof.

The morphometric dimensions for head: area $\left(\mathrm{A} ; \mu \mathrm{m}^{2}\right)$, perimeter $(\mathrm{P} ; \mu \mathrm{m})$, head length $(\mathrm{L} ; \mu \mathrm{m})$, head width $(\mathrm{W} ; \mu \mathrm{m})$ and four derived parameters of head shape: ellipticity $(\mathrm{L} / \mathrm{W})$, roughness $\left(\mathrm{P}^{2} / 4 \pi \mathrm{A}\right)$, elongation $([\mathrm{L}-\mathrm{W}] /[\mathrm{L}+\mathrm{W}])$, and regularity $(\pi \mathrm{LW} / 4 \mathrm{~A})$ were properly measured from 150 sperm heads. The measurements of individual sperm head were saved in an Excel (Microsoft Corporation) compatible database by the sperm image analysis software for further analysis.

\section{Flow cytometric analysis}

Plasma and acrosomal membrane integrity as well as mitochondrial function of thawed sperm were evaluated by flow cytometry using quadruple-staining as described by Tabarez et al. (2017). The following fluorescent probes were used: LIVE/DEAD ${ }^{\circledR}$ sperm viability kit (SYBR-14 and Propidium Iodide (PI); L7011, Invitrogen SA) for plasma membrane integrity (viability), PE-PNA (GTX01509, Antibody, Ben SL) for acrosome integrity and Mitotracker deep red (M22426, SA Invitrogen) for the detection of mitochondrial activity.

The analysis was done using a final concentration of $1 \mathrm{nM}$ of SYBR-14 (diluted in DMSO), $1.5 \mu \mathrm{M}$ of PI, $2.5 \mu \mathrm{g} / \mathrm{mL}$ PE-PNA ( $1 \mathrm{mg} / \mathrm{mL}$ of stock solution in a buffer composed of $3.0 \mathrm{M}$ ammonium sulfate, $50 \mathrm{mM}$ sodium phosphate and $0.05 \%$ sodium azide, pH 7.0 containing $1 \mathrm{mM}\left[\mathrm{Ca}^{2+}\right]$ and $\left[\mathrm{Mn}^{2+}\right]$ ions) and $1.5 \mathrm{nM}$ of Mitotracker deep red (diluted in DMSO) with $1 \mathrm{~mL}$ of sperm diluted in PBS to a final concentration of $1 \times 10^{6} / \mathrm{mL}$. Samples were mixed and incubated at $37^{\circ} \mathrm{C}$ for $10 \mathrm{~min}$. and then remixed just before analysis. Stained sperm suspensions were subsequently run through a flow cytometer. Fluorescent probes SYBR-14, PE-PNA and PI were excited in the flow cytometer using a 488-nm blue solid-state laser while the Mitotracker deep red was excited using a 633$\mathrm{nm} \mathrm{He} / \mathrm{Ne}$ excitation laser. The equipment used was the BD FACSCanto flow cytometer (BD Biosciences, CA) and samples were analyzed using BD FACSDiva (BD
Biosciences, CA).

Dead cells became PI-positive, and their red fluorescent signal was determined using filter detector 679LP (detection of emitted photons with a wavelength $>670 \mathrm{~nm}$ ). Living cells were SYBR-14 positive, and its green fluorescent signal was detected using filter detector 530/30BP (detects emitted photons with wavelength of 515-545 nm). Acrosome-damage cells were stained positively for PE-PNA, and its orange fluorescent signal was determined using filter detector $585 / 42 \mathrm{BP}$ (detects emitted photons in the wavelength of 564-650 nm). Sperm mitochondrial function was assessed with Mitotracker deep red using filter detector $660 / 20 \mathrm{BP}$. This dye is sequestered in mitochondria and emits red fluorescence in active mitochondria (high mitochondrial membrane potential).

This staining with four simultaneous fluorescences had minimal emission overlap and therefore compensation is adjusted for emission detectors used with the respective compensating controls. Non-sperm events were gated out of analysis, judged on scatter properties as observed in the forwardscatter (FSC) and side-scatter light (SSC) (scatter-gated sperm analysis). In addition, events with scatter characteristics similar to sperm cells but without DNA content (very weak SYBR-14 or PI staining) were also gated out (doubly-gated sperm analysis).

The flow cytometer was calibrated each day with calibration beads Rainbow 8 peaks (SpheroTM) and used at the average flow rate $(60 \mu \mathrm{L} / \mathrm{min})$. The recording of scatter and fluorescent properties of all events stopped when 20,000 double-gated events were recorded. The sperm populations were divided by regions and quadrants.

As the following flow cytometry cytographs shows in the Figure 1, all events are shown in graph A. Graph B relates to sperm staining and analysis of closed dispersion allowing the removal of egg yolk particles and other debris. The elimination by shape and complexity of sperm cell aggregates is shown in graph C. In graph D, only individual sperm events are showed; viable (green plots, SYBR $14^{+} / \mathrm{PI}^{-}$) and dead cells (red and orange plots, both SYBR14 $/ \mathrm{PI}^{+}$) are observed and the graph E shows damaged acrosome sperms (orange plots) from the total sperm population.

After evaluation, the spermatozoa were separated into eight populations: viable cells with intact acrosome and active mitochondria (SYBR14 $/ \mathrm{IP}^{-} / \mathrm{PE}-$ $\mathrm{PNA}^{-} /$Mitotracker $\left.^{+}\right)$; viable cells with damaged acrosome and active mitochondria (SYBR14 ${ }^{+} / \mathrm{IP}^{-} / \mathrm{PE}-$ $\mathrm{PNA}^{+} /$Mitotracker $^{+}$); viable cells with intact acrosome and inactive mitochondria (SYBR14 ${ }^{+} / \mathrm{IP}^{-} / \mathrm{PE}^{-\mathrm{PNA}^{-}}$ /Mitotracker ${ }^{-}$); viable cells with damaged acrosome and inactive mitochondria (SYBR $14^{+} / \mathrm{IP}^{-} / \mathrm{PE}^{-\mathrm{PNA}^{+} /}$ Mitotracker); dead cells with intact acrosome and active mitochondria (SYBR14 $/ \mathrm{IP}^{+} / \mathrm{PE}-\mathrm{PNA}^{-} /$Mitotracker $^{+}$); dead cells with damaged acrosome and active mitochondria $\left(\mathrm{SYBR}^{-} / \mathrm{IP}^{+} / \mathrm{PE} \mathrm{PNA}^{+} / \mathrm{Mitotracker}^{+}\right)$; dead cells with intact acrosome and inactive mitochondrial (SYBR14 $\left./ \mathrm{IP}^{+} / \mathrm{PE}-\mathrm{PNA}^{-} / \mathrm{Mitotracker}^{-}\right)$and dead cells with damaged acrosome and inactive mitochondria (SYBR14//IP ${ }^{+} /$PE-PNA ${ }^{+} /$Mitotracker-). 
(A) All Events

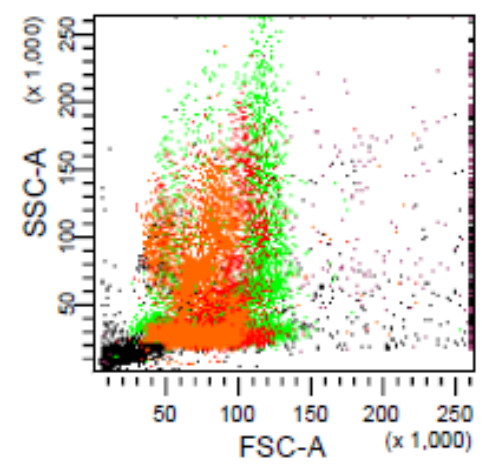

(D) Individual Sperm Events

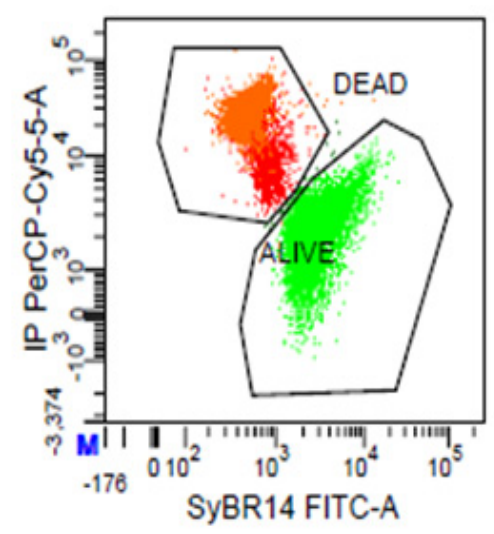

(B) Total sperm population

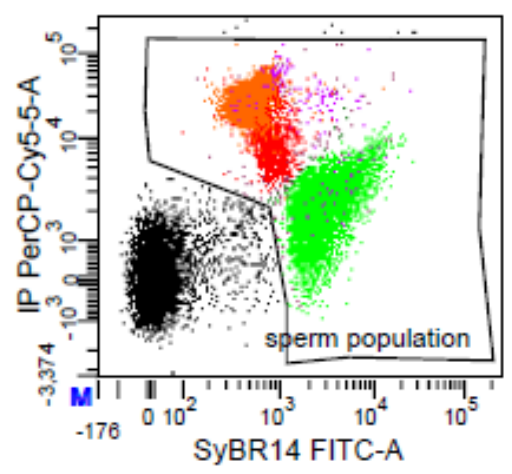

(E) Acrosome damage
(C) Non aggregate cells

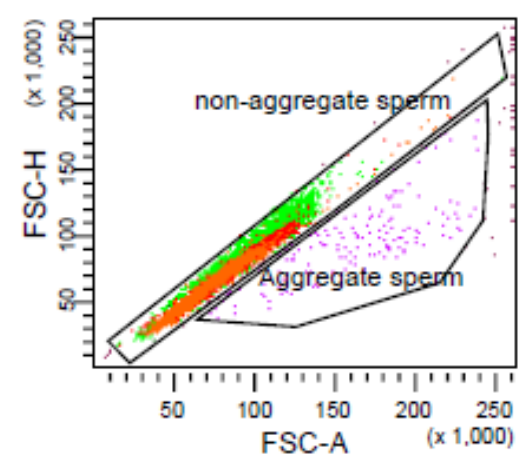

Figure1. The above flow cytometry cytographs show the behavior of the ram thawed sperm after being subjected to the quadruple staining process using fluorescent probes SYBR14/PI/PE-PNA/Mitotracker deep red.

\section{Statistical analysis}

The data were presented as means and standard error of the mean ( \pm S.E.M.). The data obtained from the analysis of all sperm parameters were subjected to tests of normality and homoscedasticity Shapiro-Wilk and Levene, respectively. Where necessary, data were arc-sin transformed. The data were analyzed using analysis of variance performed with GLM procedure (SPSS 20.0; SPSS Inc., Chicago, IL., EEUU) in a factorial design, including as fixed effects male age (1 vs 2 years old), egg yolk type (fresh, powdered and clarified), and sperm washing (washed and nonwashed). Differences between means were analyzed by Bonferroni test.

\section{Results}

Sperm analysis of the mixture of fresh ram semen indicates that donor age is an important factor on all the assessed sperm parameters, showing higher quality in those samples provided by two years old males when compared with the samples obtained in one year old with significant differences in sperm concentration $\left(3.520 \pm 248.6 \times 10^{6}\right.$ vs $2.996 \pm 105.2 \times 10^{6}$ sperm $/ \mathrm{mL}, \mathrm{P}<0.001)$, sperm viability estimated by $\mathrm{E} / \mathrm{N}$ $(87.4 \pm 1.0$ vs $74.9 \pm 3.2 ; \mathrm{P}<0.004)$ and membrane functional integrity after the hypo-osmotic test $(62.3 \pm 1.6$ vs $30.4 \pm 4.8 ; \mathrm{P}<0.0001)$. Similar results among donors were obtained on mass motility $(2.8 \pm 0.2$ vs $2.3 \pm 0.1$; $\mathrm{P}<0.062)$ and sperm abnormalities $(26.5 \pm 3.2 v s$ $28.5 \pm 3.7 ; \mathrm{P}<0.087$ ) in semen from animals of two and one years old, respectively).

Kinetic parameter evaluation after thawing indicated a significant effect of the donor age. Table 1 shows a significant increase in total sperm motility in the samples collected from two years old males when sperm (washed and unwashed) were preserved in powdered egg yolk and in washed sperm preserved in clarified egg yolk. Also, a significant increase in progressive motility was observed in sperm from older males irrespective of the preservation protocol used, as well as in the other kinetic parameters except in the lateral head displacement (ALH). Regards the straightness coefficient (\%STR), there was no significant difference in washed and unwashed sperm preserved in CEY and in unwashed sperm preserved in PEY, although the tendency seems to exist. On the other hand, neither the type of egg yolk nor the semen washing had any significant effect on the total sperm motility despite the slight increase of values when the sperm were preserved without the presence of seminal plasma in both donor ages.

However, the kinetic descriptor results showed significant differences depending on the preservation treatment and donor age without following a clear tendency, especially, in sperm from 1 year old males. In order to synthetize these results, velocities values were generally higher in washed sperm from older rams, 
except for washed sperm preserved in PEY. In fact, sperm linearity (LIN) showed significant differences among treatments, but without a clear effect of egg yolk type or sperm washing. This was observed in washed sperm preserved in FEY which showed the lowest values $(36.4 \pm 1.0 \%)$ during the first year of age of the donors and the highest LIN $(58.1 \pm 3.7 \%)$ during the second year using the same protocol, but showed significant differences compared to other treatments. No significant differences were found on the lateral head displacement (ALH) among treatments, only washed sperm preserved in CEY presented a higher ALH compared to values obtained on unwashed sperm preserved in PEY or FEY. Finally, some differences among treatments were found in BCF but without a clear effect with the presence of seminal plasma or the egg yolk used on sperm from one year old ram sperm, although this parameter was significantly higher in sperm from older males preserved in FEY, regardless of the presence or absence of seminal plasma.

From 9,850 frozen-thawed analysed sperm, no effect from the preservation treatment or the age of the donor was observed after morphometric analysis of the sperm head by CASA system. All sperm showed similar morphometric dimensions for head as area $\left(34.2 \pm 0.1 \mu \mathrm{m}^{2}\right)$, perimeter $(23.4 \pm 0.1 \mu \mathrm{m})$, length $(8.4 \pm 0.0 \mu \mathrm{m} \mathrm{L} ; \mu \mathrm{m})$, width $(4.9 \pm 0.0 \mu \mathrm{m})$, and for the four derived parameters of head shape as ellipticity $(1.7 \pm 0.0)$, elongation $(0.2 \pm 0.0)$, roughness $(0.8 \pm 0.0)$ and regularity $(0.9 \pm 0.0)$.

Table 1. Effect of donor age, type of egg yolk used as cryoprotectant on kinetic parameters of washed and nonwashed ram spermatozoa after thawing

\begin{tabular}{|c|c|c|c|c|c|c|c|}
\hline Parameter & Age & W-FEY & W-PEY & W-CEY & FEY & PEY & CEY \\
\hline TM (\%) & $\begin{array}{l}1 \\
2\end{array}$ & $\begin{array}{l}46.7 \pm 8.8 \\
51.4 \pm 4.8\end{array}$ & $\begin{array}{l}42.5 \pm 3.6^{1} \\
52.4 \pm 3.9^{2}\end{array}$ & $\begin{array}{l}41.6 \pm 1.4^{1} \\
49.2 \pm 4.9^{2}\end{array}$ & $\begin{array}{l}38.9 \pm 6.9 \\
39.9 \pm 7.1\end{array}$ & $\begin{array}{l}39.1 \pm 6.8^{1} \\
51.5 \pm 2.5^{2}\end{array}$ & $\begin{array}{l}36.2 \pm 7.2 \\
39.8 \pm 4.4\end{array}$ \\
\hline PM (\%) & $\begin{array}{l}1 \\
2\end{array}$ & $\begin{array}{l}20.1 \pm 3.2^{\mathrm{a} 1} \\
29.8 \pm 2.4^{\mathrm{a} 2}\end{array}$ & $\begin{array}{l}16.7 \pm 1.7^{\mathrm{b} 1} \\
21.9 \pm 2.8^{\mathrm{b} 2}\end{array}$ & $\begin{array}{l}15.0 \pm 1.6^{\mathrm{b} 1} \\
22.2 \pm 3.6^{\mathrm{b} 2}\end{array}$ & $\begin{array}{l}17.9 \pm 1.2^{\mathrm{ab} 1} \\
22.5 \pm 3.9^{\mathrm{b} 2}\end{array}$ & $\begin{array}{l}16.3 \pm 2.8^{\mathrm{b} 1} \\
27.9 \pm 4.5^{\mathrm{a} 2}\end{array}$ & $\begin{array}{l}13.9 \pm 2.5^{\mathrm{b} 1} \\
15.1 \pm 2.3^{\mathrm{c} 2}\end{array}$ \\
\hline $\begin{array}{l}\text { VCL } \\
(\mu \mathrm{m} / \mathrm{s})\end{array}$ & $\begin{array}{l}1 \\
2\end{array}$ & $\begin{array}{l}69.4 \pm 5.6^{\mathrm{a} 1} \\
97.8 \pm 5.8^{\mathrm{a} 2}\end{array}$ & $\begin{array}{l}58.4 \pm 4.8^{\mathrm{b} 1} \\
86.9 \pm 2.6^{\mathrm{b} 2}\end{array}$ & $\begin{array}{l}63.0 \pm 2.3^{\mathrm{b} 1} \\
96.3 \pm 3.7^{\mathrm{a} 2}\end{array}$ & $\begin{array}{l}61.7 \pm 3.3^{\mathrm{b} 1} \\
83.6 \pm 5.2^{\mathrm{b} 2}\end{array}$ & $\begin{array}{l}68.8 \pm 6.1^{\mathrm{ab} 1} \\
83.4 \pm 5.9^{\mathrm{b} 2}\end{array}$ & $\begin{array}{l}59.1 \pm 6.7^{\mathrm{b} 1} \\
82.9 \pm 5.5^{\mathrm{b} 2}\end{array}$ \\
\hline $\operatorname{VSL}(\mu \mathrm{m} / \mathrm{s})$ & $\begin{array}{l}1 \\
2\end{array}$ & $\begin{array}{l}24.2 \pm 2.8^{\mathrm{ab} 1} \\
58.8 \pm 7.2^{\mathrm{a} 2}\end{array}$ & $\begin{array}{l}21.4 \pm 2.2^{\mathrm{a} 1} \\
41.3 \pm 2.2^{\mathrm{bc} 2}\end{array}$ & $\begin{array}{l}23.4 \pm 1.3^{\mathrm{a} 1} \\
49.3 \pm 4.2^{\mathrm{ad} 2}\end{array}$ & $\begin{array}{l}25.9 \pm 1.0^{\mathrm{ab} 1} \\
47.6 \pm 4.9^{\mathrm{bd} 2}\end{array}$ & $\begin{array}{l}27.2 \pm 3.9^{\mathrm{b} 1} \\
44.7 \pm 7.9^{\mathrm{bd} 2}\end{array}$ & $\begin{array}{l}21.3 \pm 3.4^{\mathrm{a} 1} \\
37.9 \pm 5.1^{\mathrm{c} 2}\end{array}$ \\
\hline $\mathrm{VAP}(\mu \mathrm{m} / \mathrm{s})$ & $\begin{array}{l}1 \\
2\end{array}$ & $\begin{array}{l}37.8 \pm 3.5^{\mathrm{a} 1} \\
73.2 \pm 6.8^{\mathrm{a} 2}\end{array}$ & $\begin{array}{l}33.2 \pm 2.9^{\mathrm{b} 1} \\
59.2 \pm 2.1^{\mathrm{bc} 2}\end{array}$ & $\begin{array}{l}33.9 \pm 1.7^{\mathrm{b} 1} \\
65.6 \pm 4.4^{\mathrm{a} 2}\end{array}$ & $\begin{array}{l}35.4 \pm 1.3^{\mathrm{ab} 1} \\
58.7 \pm 4.6^{\mathrm{bc} 2}\end{array}$ & $\begin{array}{l}39.0 \pm 4.0^{\mathrm{a} 1} \\
59.8 \pm 7.4^{\mathrm{bc} 2}\end{array}$ & $\begin{array}{l}32.7 \pm 3.9^{\mathrm{b} 1} \\
52.8 \pm 5.1^{\mathrm{c} 2}\end{array}$ \\
\hline LIN (\%) & $\begin{array}{l}1 \\
2\end{array}$ & $\begin{array}{l}36.4 \pm 1.0^{\mathrm{a} 1} \\
58.1 \pm 3.7^{\mathrm{a} 2}\end{array}$ & $\begin{array}{l}39.1 \pm 1.0^{\mathrm{b} 1} \\
47.8 \pm 2.1^{\mathrm{b} 2}\end{array}$ & $\begin{array}{l}39.6 \pm 2.5^{\mathrm{b} 1} \\
49.9 \pm 2.4^{\mathrm{bc} 2}\end{array}$ & $\begin{array}{l}44.2 \pm 2.2^{\mathrm{c} 1} \\
53.9 \pm 2.9^{\mathrm{c} 2}\end{array}$ & $\begin{array}{l}40.3 \pm 1.9^{\mathrm{bc} 1} \\
51.5 \pm 4.8^{\mathrm{bc} 2}\end{array}$ & $\begin{array}{l}38.9 \pm 1.7^{\mathrm{ab} 1} \\
43.8 \pm 2.5^{\mathrm{d} 2}\end{array}$ \\
\hline STR (\%) & $\begin{array}{l}1 \\
2\end{array}$ & $\begin{array}{l}61.9 \pm 2.3^{\mathrm{a} 1} \\
77.1 \pm 2.6^{\mathrm{a} 2}\end{array}$ & $\begin{array}{l}63.5 \pm 1.3^{\mathrm{ab} 1} \\
68.2 \pm 1.4^{\mathrm{b} 2}\end{array}$ & $\begin{array}{l}66.3 \pm 2.3^{\mathrm{b}} \\
69.6 \pm 1.6^{\mathrm{b}}\end{array}$ & $\begin{array}{l}70.3 \pm 1.2^{\mathrm{c} 1} \\
76.3 \pm 2.6^{\mathrm{ac} 2}\end{array}$ & $\begin{array}{l}65.9 \pm 2.6^{\mathrm{b}} \\
71.4 \pm 3.8^{\mathrm{bc}}\end{array}$ & $\begin{array}{l}63.1 \pm 2.8^{\mathrm{ab}} \\
64.9 \pm 1.8^{\mathrm{d}}\end{array}$ \\
\hline $\operatorname{ALH}(\mu \mathrm{m} / \mathrm{s})$ & $\begin{array}{l}1 \\
2\end{array}$ & $\begin{array}{l}3.2 \pm 0.2 \\
3.1 \pm 0.6^{\mathrm{ab}}\end{array}$ & $\begin{array}{l}2.8 \pm 0.2 \\
3.3 \pm 0.2^{\mathrm{ab}}\end{array}$ & $\begin{array}{l}2.9 \pm 0.1 \\
3.6 \pm 0.1^{b}\end{array}$ & $\begin{array}{l}2.8 \pm 0.1 \\
3.0 \pm 0.1^{\mathrm{a}}\end{array}$ & $\begin{array}{l}3.1 \pm 0.2 \\
3.1 \pm 0.1^{\mathrm{a}}\end{array}$ & $\begin{array}{l}2.9 \pm 0.3 \\
3.3 \pm 0.1^{\mathrm{ab}}\end{array}$ \\
\hline $\mathrm{BCF}(\mathrm{Hz})$ & $\begin{array}{l}1 \\
2\end{array}$ & $\begin{array}{r}6.4 \pm 0.9^{\mathrm{ab} 1} \\
10.8 \pm 0.6^{\mathrm{a} 2}\end{array}$ & $\begin{array}{l}6.2 \pm 0.6^{\mathrm{ac} 1} \\
9.0 \pm 0.2^{\mathrm{b} 2}\end{array}$ & $\begin{array}{l}6.9 \pm 0.5^{\mathrm{ab} 1} \\
8.7 \pm 0.5^{\mathrm{bc} 2}\end{array}$ & $\begin{array}{l}7.5 \pm 0.7^{\mathrm{b} 1} \\
9.9 \pm 0.5^{\mathrm{a} 2}\end{array}$ & $\begin{array}{l}6.7 \pm 0.6^{\mathrm{ab} 1} \\
8.9 \pm 0.7^{\mathrm{bc} 2}\end{array}$ & $\begin{array}{l}5.5 \pm 0.8^{\mathrm{c} 1} \\
8.1 \pm 0.8^{\mathrm{c} 2}\end{array}$ \\
\hline
\end{tabular}

${ }^{\mathrm{a}, \mathrm{d}}$ Different letter in the row indicates statistical difference $(\mathrm{P}<0.001)$ among treatments. ${ }^{1,2}$ Different number in the column for the same parameter indicates statistical difference between donor ages. FEY: fresh egg yolk; PEY: powder egg yolk; CEY: clarified egg yolk; W: washed sperm; TM: total motility; PM: progressive motility; VCL: Curvilinear velocity; VSL: Linear velocity; VAP: Mean velocity; LIN: Linear coefficient; STR: Straightness coefficient; ALH: Lateral head displacement; BCF: Frequency of head displacement. Number of spermatozoa $=7.592$.

However, the flow cytometry analysis (Tab. 2) showed that the age of the donor affected significantly $(\mathrm{P}<0.0001)$ the viability, acrosomal integrity and mitochondrial activity of the thawed sperm, obtaining higher values in the two years old males in all the studied treatments, but without affecting the incidence of alive cells with damaged acrosome. Also, the removal of seminal plasma had a significant effect on sperm survival after thawing, showing higher results on washed sperm irrespective on the type of egg yolk used or the age of the donors. On the other hand, the incidence of alive sperm with damaged acrosome was lower when the sperm, independently of the age of the donor, were preserved in the presence of seminal plasma and also in washed sperm preserved in powdered egg yolk. It is worthy to note the high incidence of sperm with low mitochondrial activity in sperm preserved in clarified egg yolk.

Finally, non-significant interactions among the different factors were observed for most of the analysed traits, except the interactions found $(\mathrm{P}<0.05)$ between egg yolk type $\mathrm{x}$ sperm washing for the trait of alive sperm with acrosome damaged and inactive mitochondria and for the straightness coefficient (STR). Also, another 
García et al. Egg yolk, seminal plasma and ram age on thawed sperm.

interaction was observed between male age $\mathrm{x}$ sperm washing for mean velocity (VAP) as between male age $\mathrm{x}$ egg yolk type for the straightness coefficient (STR) and for the lateral head displacement (ALH).

Table 2. Effect of donor age and type of egg yolk on viability, mitochondrial activity and acrosomal damage of washed and non-washed sperm after thawing.

\begin{tabular}{|c|c|c|c|c|c|c|c|}
\hline $\begin{array}{l}\text { Sperm Cell } \\
\text { Population } \\
(\%)\end{array}$ & Age & W-FEY & W-PEY & W-CEY & FEY & PEY & CEY \\
\hline Viability & $\begin{array}{l}1 \\
2\end{array}$ & $\begin{array}{l}34.5 \pm 4.8^{\mathrm{a} 1} \\
47.8 \pm 1.5^{\mathrm{a} 2}\end{array}$ & $\begin{array}{l}36.5 \pm 2.5^{\mathrm{a} 1} \\
48.9 \pm 3.2^{\mathrm{a} 2}\end{array}$ & $\begin{array}{l}33.8 \pm 2.6^{\mathrm{a} 1} \\
45.3 \pm 3.5^{\mathrm{a} 2}\end{array}$ & $\begin{array}{l}21.4 \pm 1.7^{\mathrm{b} 1} \\
33.9 \pm 3.9^{\mathrm{b} 2}\end{array}$ & $\begin{array}{l}23.1 \pm 3.7^{\mathrm{b} 1} \\
37.1 \pm 1.6^{\mathrm{b} 2}\end{array}$ & $\begin{array}{l}24.3 \pm 2.7^{\mathrm{b} 1} \\
29.8 \pm 5.1^{\mathrm{b} 2}\end{array}$ \\
\hline $\begin{array}{l}\text { Intact acrosome, } \\
\text { Active mitochondria }\end{array}$ & $\begin{array}{l}1 \\
2\end{array}$ & $\begin{array}{l}28.3 \pm 3.5^{\mathrm{ab} 1} \\
39.4 \pm 1.8^{\mathrm{a} 2}\end{array}$ & $\begin{array}{l}31.9 \pm 2.4^{\mathrm{b} 1} \\
41.7 \pm 3.0^{\mathrm{a} 2}\end{array}$ & $\begin{array}{l}27.3 \pm 1.3^{\mathrm{a} 1} \\
36.5 \pm 2.6^{\mathrm{a} 2}\end{array}$ & $\begin{array}{l}18.2 \pm 2.1^{\mathrm{c} 1} \\
29.6 \pm 3.9^{\mathrm{bc} 2}\end{array}$ & $\begin{array}{l}20.4 \pm 2.8^{\mathrm{c} 1} \\
32.3 \pm 1.9^{\mathrm{b} 2}\end{array}$ & $\begin{array}{l}20.8 \pm 2.3^{\mathrm{c} 1} \\
24.0 \pm 4.5^{\mathrm{c} 2}\end{array}$ \\
\hline $\begin{array}{l}\text { Damaged } \\
\text { acrosome, } \\
\text { Active mitochon }\end{array}$ & $\begin{array}{l}1 \\
2\end{array}$ & $\begin{array}{l}3.7 \pm 0.2^{\mathrm{a} 1} \\
4.3 \pm 0.6^{\mathrm{a} 1}\end{array}$ & $\begin{array}{l}1.3 \pm 0.2^{\mathrm{b} 1} \\
2.2 \pm 0.2^{\mathrm{ab} 1}\end{array}$ & $\begin{array}{l}3.2 \pm 0.8^{\mathrm{a} 1} \\
3.5 \pm 0.5^{\mathrm{a} 1}\end{array}$ & $\begin{array}{l}2.3 \pm 0.4^{\mathrm{ab} 1} \\
2.4 \pm 0.1^{\mathrm{ab} 1}\end{array}$ & $\begin{array}{l}1.0 \pm 0.2^{\mathrm{b} 1} \\
2.2 \pm 0.3^{\mathrm{ab} 1}\end{array}$ & $\begin{array}{l}1.7 \pm 0.5^{\mathrm{b} 1} \\
1.3 \pm 0.2^{\mathrm{b} 1}\end{array}$ \\
\hline $\begin{array}{l}\text { Intact acrosome, } \\
\text { Inactive } \\
\text { mitochondria }\end{array}$ & $\begin{array}{l}1 \\
2\end{array}$ & $\begin{array}{l}2.0 \pm 0.6^{\mathrm{a} 1} \\
3.5 \pm 0.5^{\mathrm{ab} 2}\end{array}$ & $\begin{array}{l}3.2 \pm 0.3^{\mathrm{b} 1} \\
4.7 \pm 0.8^{\mathrm{a} 2}\end{array}$ & $\begin{array}{l}2.0 \pm 0.4^{\mathrm{a} 1} \\
3.9 \pm 0.6^{\mathrm{a} 2}\end{array}$ & $\begin{array}{l}0.7 \pm 0.2^{\mathrm{c} 1} \\
1.7 \pm 0.4^{\mathrm{c} 2}\end{array}$ & $\begin{array}{l}1.6 \pm 0.6^{\mathrm{a} 1} \\
2.5 \pm 0.9^{\mathrm{bc} 2}\end{array}$ & $\begin{array}{l}2.1 \pm 0.3^{\mathrm{a} 1} \\
4.1 \pm 2.4^{\mathrm{ab} 2}\end{array}$ \\
\hline $\begin{array}{l}\text { Damaged } \\
\text { acrosome, } \\
\text { Inactive mitochon }\end{array}$ & $\begin{array}{l}1 \\
2\end{array}$ & $\begin{array}{l}0.5 \pm 0.3^{\mathrm{b} 1} \\
0.6 \pm 0.1^{\mathrm{a} 1}\end{array}$ & $\begin{array}{l}0.1 \pm 0.0^{\mathrm{b} 1} \\
0.2 \pm 0.1^{\mathrm{b} 1}\end{array}$ & $\begin{array}{l}1.3 \pm 1.0^{\mathrm{a} 1} \\
1.4 \pm 0.6^{\mathrm{cl}}\end{array}$ & $\begin{array}{l}0.2 \pm 0.1^{\mathrm{b} 1} \\
0.2 \pm 0.1^{\mathrm{b} 1}\end{array}$ & $\begin{array}{l}0.1 \pm 0.0^{\mathrm{b} 1} \\
0.1 \pm 0.0^{\mathrm{b} 1}\end{array}$ & $\begin{array}{l}0.1 \pm 0.2^{\mathrm{b} 1} \\
0.4 \pm 0.3^{\mathrm{ab} 1}\end{array}$ \\
\hline $\begin{array}{l}\text { Acrosome } \\
\text { Integrity }\end{array}$ & $\begin{array}{l}1 \\
2\end{array}$ & $\begin{array}{l}54.3 \pm 2.7^{\mathrm{a} 1} \\
66.6 \pm 2.3^{\mathrm{a} 2}\end{array}$ & $\begin{array}{l}58.0 \pm 2.9^{\mathrm{a} 1} \\
65.0 \pm 3.6^{\mathrm{a} 2}\end{array}$ & $\begin{array}{l}56.5 \pm 3.0^{\mathrm{a} 1} \\
65.2 \pm 3.9^{\mathrm{a} 2}\end{array}$ & $\begin{array}{l}43.8 \pm 3.7^{\mathrm{b} 1} \\
50.2 \pm 3.9^{\mathrm{b} 2}\end{array}$ & $\begin{array}{l}44.0 \pm 3.1^{\mathrm{b} 1} \\
51.9 \pm 2.3^{\mathrm{b} 2}\end{array}$ & $\begin{array}{l}40.2 \pm 2.6^{\mathrm{b} 1} \\
49.8 \pm 2.0^{\mathrm{b} 2}\end{array}$ \\
\hline
\end{tabular}

${ }^{\mathrm{a}, \mathrm{d}}$ Different letter in the row indicates statistical difference $(\mathrm{P}<0.001)$ among treatments. ${ }^{1,2}$ Different number in the column for the same parameter indicates statistical difference between donor ages. Extenders: FEY: fresh egg yolk; PEY: powder egg yolk; CEY: clarified egg yolk; W: washed sperm.

\section{Discussion}

In the present study, one of the objectives was to compare the cryoprotective capacity of fresh egg yolk with clarified egg yolk (removal of egg yolk compounds (granules) to obtain a concentrated amount of LDL), and powdered egg yolk (removal of bacterial contamination by pasteurization). After thawing, no significant differences were found among the different type of egg yolk extenders on their protective capacity acording to plasma and acrosomal membrane integrity, mitochondrial activity, as well the total sperm movement or morphometry of the thawed spermatozoa. Similar results were described by Marco-Jimenez et al. (2004) when they compared fresh to powdered egg yolk in ovine sperm from Guirra breed on acrosome integrity, although a significant increase in total motility was detected when the sperm were preserved in powdered egg yolk. Also, Wall and Foote (1999) did not observe any differences in bovine sperm viability and fertility when comparing clarified to fresh egg yolk, while Fernández-Santos et al. (2006) observed higher sperm quality using clarified egg yolk during the cryopreservation of Iberian red deer spermatozoa. An explanation of these differences among species may be due to the different composition of plasma membrane, the percentage of egg yolk included in the extender, the time of refrigeration and/or the freezing method (Fernández-Santos et al., 2006).

However, as regards to sperm movement quality, we observed significant differences depending on the yolk type used. Specifically, fresh egg yolk seems to provide a higher percentage of progressive motility, whereas the powdered egg yolk (PEY) provoked a decrease on curvilinear velocity (VCL) of sperm from males of one and two years old, as well decreasing the VSL and LIN, especially in the 2 years old male sperm samples preserved in PEY. This decline on the sperm kinetic parameters could be due to the increase of extender viscosity when PEY is used, as Marco-Jiménez et al. (2004) also observed. This high viscosity of the extender after the reconstitution of the powdered egg yolk in the media seems to be as result of the high temperatures used during the pasteurization process and this may denaturalize the egg yolk proteins giving higher gelatinous consistency (Miranda et al., 2000). Nevertheless, the differences seen among the 3 types of egg yolk related to their cryopreservation capacity could be considered negligible.

On the other hand, according to our results, sperm washing by centrifugation provided a beneficial effect on ram sperm cryopreservation as seen in sperm viability, membrane integrity and most of the kinetic parameters after thawing. However, the cause for this higher survival could be due to various reasons. One reason may be that the removal of seminal plasma from cryopreservation extenders could improve the protective capacity of the egg yolk against the cold shock as described in different species like rabbit (Ritar and Salamon, 1991), buck (Aboagla and Terada, 2003; 
Bispo et al., 2011), boar (Bathgate et al., 2006) or horse (Martin et al., 1979), suggesting a negative interaction between seminal plasma and egg yolk, thus affecting motility. Another explanation could be that the technique used to separate seminal plasma through centrifugation may also have eliminated a high percentage of damaged and dead sperm cells (Cebrián et al., 2010).

Nevertheless, there is still an important controversy as regards the need to remove seminal plasma prior to sperm preservation. While some authors remark the importance of the plasma seminal in the preservation of motility and viability in ram thawed sperm (Graham, 1994; Maxwell and Watson 1996), other researchers describe harmful effects (Schmehl et al., 1986). In any case, we should consider that seminal plasma composition varies between species, males and environmental factors like season of collection, temperature, nutrition or stress (Pérez-Pé et al., 2001; Muiño-Blanco et al., 2008). However, in the present study, while plasma removal increased sperm survival, sperm preserved in presence of seminal plasma showed lower proportions of alive sperm with damaged acrosome. In other words, seminal plasma seemed to have protected the sperm from undergoing the cryocapacitation process. Also, it is noteworthy to mention that when washed sperm were preserved in PEY extenders, the cryocapacitated sperm population was also lower compared to the other freezing protocols.

With regards to the age of the donors, semen quality assessed just after collection was superior in males of 2 years old males. These results may probably be due the fact that one year old males could have not completed their body growth and sexual maturity (Beltrán de Heredia 2009). Similarly, Martinez et al. (1998) showed that sperm concentration and viability were higher in adult rams (3-4 years old) compared to one year old individuals. Further confounding this result was demonstrated by Colas and Zinsner (1975) who showed that fertility increased as the donor age increase from one to two years old males.

This superiority on sperm quality in the older males remains along the freezing-thawing process showing higher values on viability, acrosome integrity and high mitochondrial activity in all the studied treatments. Similar results on thawed sperm were reported by Lymberopoulos et al. (2010) in 4-5 years old rams when compared with 1-2 years old animals, showing an increase in fertility and prolificacy. Likewise, Rodríguez-Almeida et al. (2008) found higher values of acrosome reaction on frozen-thawed sperm from younger animals (1 years old), compared to sperm from adult rams, but without significant differences on viability.

Also, the quantity and quality of sperm movement after thawing seemed to be affected by the age of the donors with older males having better results. A significant increase was observed in all the descriptive kinetic parameters of thawed sperm, regardless of the cryopreservation method used, except in ALH. Progressive motility after thawing was significant higher in sperm from older males, suggesting that the donor age not only affected the quality of fresh ejaculates but also improved the capacity of the sperm to resist the cryopreservation. Only, total motility was affected in different manner depending on the cryopreservation protocol. Specifically, a higher total motility was observed in (washed and unwashed) sperm from older males preserved in PEY extender and in washed sperm preserved in CEY extender. Thus, it has been shown that kinetic characteristics of thawed sperm could be affected by sexual maturity of rams (Rodríguez-Almeida et al., 2008), and in adult bucks (Cabrera et al., 1998) who also reported higher progressive sperm motility in older males than in younger ones. However, the size and shape of the head of thawed sperm were not affected by the donor age, the absence or presence of seminal plasma or the type of egg yolk used during the cryopreservation, showing similar values as described in rams (Maroto-Morales, 2012; Bravo, 2010).

In conclusion, our results suggest that semen collected from 2 years old rams have higher concentration, good quality and better survival to the cryopreservation process than semen from younger males. Also the removal of seminal plasma through centrifugation improved the sperm survival of frozenthawed sperm. Moreover, this study showed that powdered egg yolk can be used to replace fresh egg yolk thus ensuring greater bio-security measures due to the pasteurization process and a more homogeneous composition of the extenders. However, the fertilizing capacity of sperm preserved in this type of egg yolk is still unknown and more studies through in vitro or in vivo fertilization are recommended. The use of clarified egg yolk did not show any advantage to fresh egg yolk but further complicated the processes of extender preparation.

\section{Acknowledgements}

The authors thank to the IRTA (Institut de Recerca i Tecnologia Agroalimentàries, Spain) in Caldes de Montbui for their help with taking care of the semen donors. This work was supported by INIA (Instituto Nacional de Investigación y Tecnología Agraria y Alimentaria, Spain) (RZ2009-00008-00-00), Generalitat de Catalunya (Catalonian Government, Spain) (2009SGR0621) and Fundación Carolina (Spanish Government, Spain).

\section{References}

Aboagla EME, Terada T. 2003. Trehalose-enhanced fluidity of the goat sperm membrane and its protection during freezing. Biol Reprod, 69(4):1245-1250.

Anton M, Martinet V, Dalgalarrondo M, Beaumal V, David-Briand E, Rabesona, AH. 2003. Chemical and structural characterisation of low-density lipoproteins purified from hen egg yolk. Food Chem, 83:175-183.

Barrios B, Pérez-Pé R, Gallego M, Tato A, Osada J, Muino-Blanco T, Cebrián-Pérez JA. 2000. Seminal plasma proteins revert the cold-shock damage on ram 
sperm membrane. Biol Reprod, 1531-1537.

Barrios B, Fernandez-Juan M, Muiño-Blanco $T$, Cebrián-Pérez JA. 2005. Immunocytochemical localization and biochemical characterization of two seminal plasma proteins that protect ram spermatozoa against cold shock. J Androl, 26:539-549.

Bathgate R, Maxwell WM, Evans G. 2006. Studies on the effect of supplementing boar semen cryopreservation media with different avian egg yolk types on in vitro post-thawsperm quality. Reprod Domes Anim, 41:68-73.

Beltrán de Heredia I. 2009. Reproducción y control reproductivo en el macho. In Sañudo C, Cepero Briz R, (Eds). Ovinotecnia; Producción y Economía de la Especie. Zaragoza, Spain Prensas Universitarias de Zaragoza, pp.105-114.

Bergeron A, Crête MH, Brindle Y, Manjunath P. 2004. Low-density lipoprotein fraction from hen's egg yolk decreases the binding of the major proteins of bovine seminal plasma to sperm and prevents lipid efflux from the sperm membrane. Biol Reprod, 70(3):708-17.

Bispo CAS, Pugliesi G, Galvão P, Rodrigues MT, Ker P, Filgueiras B. 2011. Effect of low and high egg yolk concentrations in the semen extender for goat semen cryopreservation. Small Rumin Research, 100:54-58.

Bousseau S, Brillard JP, Marquant-Le Guienne B, Guerin B, Camus A, Lechat M. 1998. Comparison of bacteriological qualities of various egg yolk sources and the in vitro and in vivo fertilizing potential of bovine semen frozen in egg yolk or lecithin based diluents. Theriogenology, 50:699-706.

Bravo J. 2010. Estudio de la influencia de la estación sobre los parámetros seminales y morfométricos del espermatozoide del morueco de la raza Ile de France. Tesis Facultad de Veterinaria. Universidad de Extremadura. Cáceres, España. 228p.

Cabrera F, González F, Batista M, Forga J, Calero P, Gracia A. 1998. Influencia de la edad y los factores ambientales sobre la producción seminal del macho de la agrupación caprina canaria (variedad Majorera) a lo largo del todo el año. XXIII Jornadas Científicas de la Sociedad Española de Ovinotecnia y Caprinotecnia. Vitoria, Spain. p.525-528

Cebrián J, Muiño-Blanco T, Pérez-Pé R, Casao A 2010. Manejo y conservación del semen. In Abecia A and Forcada $\mathrm{F}$ (Edts). Manejo reproductivo en ganado ovino. Servet, Zaragoza, Spain. pp:127-135.

Colas G, Zinsner F. 1975. Production spermatique et développement testiculaire chez l'agneau de race Ile-deFrance et Préalpes. Journées de Recherche Ovine et Caprine. Ed. ITOVIC, France, París, p.235-243.

Fernández-Santos MR, Esteso MC, Montoro V, Soler AJ, Garde JJ. 2006. Cryopreservation of Iberian red deer (Cervus elaphus hispanicus) epididymal spermatozoa:Effects of egg yolk, glycerol and cooling rate. Theriogenology, 66:1931-1942.

Folch J. 1984. Manejo reproductivo de los ovinos de carne y sus bases fisiológicas. Institución Fernando el Católico (Eds.). Zaragoza, España. p.43-46.

Forouzanfar M, Sharafi M, Hosseini SM,
Ostdadhosseini S, Hajian M, Hosseini L, Abedi P, Nili N, Rahmani HR, Nasr-Esfahani MH. 2010. In vitro comparison of egg yolk-based and soybean lecithin-based extenders for cryopreservation of ram semen. Theriogenology, 73:480-487

Graham JK. 1994. Effect of seminal plasma on the motility of epididymal and ejaculated spermatozoa of the ram and bull during the cryopreservation process. Theriogenology, 41:1151-1162.

Hancock JL. 1951. A staining technique for the study of temperature shock in semen. Nature, 167:323-324.

Holt C, Holt WV, Moore HD. 1996. Choice of operating conditions to minimize sperm subpopulation sampling bias in the assessment of boar semen by computer-assisted semen analysis. J Androl, 17:587596.

Kampschmidt RF, Mayer DT, Heman HA. 1953. Lipid and lipoprotein constituents of egg yolk in the resistance and storage of bull spermatozoa. J Dairy Sci, 36:733-742.

Lymberopoulus AG, Tsakmakidis IA, Khalifa TAA. 2010. Effect of ram age on structural and functional competence of frozen-thawed spermatozoa in dairy sheep. Reprod Dom Anim, 45, 572-578

Marco-Jimenez F, Puchades S, Moce E, Viudes-DeCartro M, Vicente J, Rodriguez M. 2004. Use of Powdered Egg Yolk vs Fresh Egg Yolk for the Cryopreservation of Ovine Semen. Reprod Dom Anim, 39:438-441.

Martin JC, Klug E, Gunzel AR. 1979. Centrifugation of stallion semen and its storage in large volume straws. Journal of Reproduction and Fertility, 27:47-51.

Martínez R, Vásquez R, Cerquera A, Espinosa $E$. 1998. Caracterización de la respuesta a criopreservación y evaluación por prueba de reacción acrosómica in vitro de la fertilidad del semen ovino. Rev Corpica Colombia, 11:90-97.

Maroto-Morales A. 2012. Evaluación objetiva de la morfometria de los espermatozoides de ovino (Ovis aries). Relacionados con la fertilidad. Facultad de Veterinaria, Universidad de Castilla-La Mancha, Spain. Thesis.

Maxwell WMC, Watson PF. 1996. Recent progress in the preservation of ram semen. Anim Reprod Sci, 42:5565.

Maxwell WMC, de Graaf SP, El-Hajj Ghaoui R, Evans G. 2007. Seminal plasma effects on sperm handling and fertility. In: Juengel JI, Murria JF and Smith MF (eds). Reproduction in Domestic Ruminants VI. Nottingham UK: Nottingham University Press, 1338 .

Miranda J, Guerrero AF, Partal P. 2000. Reología de derivados de la yema de huevo deshidratada. Grasas y Aceites. 51:244-250.

Moussa M, Martinet V, Trimeche A, Tainturier D, Anton M. 2002. Low density lipoproteins extracted from hen egg yolk by an easy method: cryoprotective effect on frozen thawed bull semen. Theriogenology, 57:1695-1706.

Muiño-Blanco T, Pérez-Pé R, Cebrián-Pérez JA. 2008. Seminal Plasma Proteins and Sperm Resistance to Stress. Reprod Dom Anim, 43(Suppl. 4):18-31. 
Pace M, Graham P. 1974. Components in egg yolk which protect bovine spermatozoa during freezing. $J$ Animal Science, 39(6):1144-1149.

Pérez-Pé R, Barrios B, Muiño-Blanco T, CebriánPérez JA. 2001. Seasonal differences in ram seminal plasma revealed by partition in anaqueous two-phase system. J Chrom B, 76:113-121.

Ritar AJ, Salamon S. 1991. Effects of month of collection, method of processing, concentration of egg yolk and duration of frozen storage on viability of Angora goat spermatozoa. Small Rumin Research, 4(1):29-37.

Rodríguez-Almeida F, Ávila CO, Anchondo A, Sánchez-Ramírez B, Jiménez JA. 2008. Capacitación espermática inducida por la conservación de semen de carnero diluido, refrigerado o congelado. AgrocienciaMexico. 42(4):399-406.

Salamon S, Maxwell WMC. 2000. Storage of ram semen. Anim Reprod Sci, 62:77-111.

Schmehl MK, Anderson SP, Vazquez IA, Graham EF. 1986. The effect of dialysis of extended ram semen prior to freezing on post-thaw survival and fertility. Cryobiology, 23:406-414.

Tabarez A, García W, Palomo MJ. 2017. Effect of the type of egg yolk, removal of seminal plasma and donor age on buck sperm cryopreservation. Small Rumin Res, 149:91-98.

Thibier M, Guerin B. 2000. Hygienic aspects of storage and use of semen for artificial insemination. Anim Reprod Sci, 62:233-251.

Wall RJ, Foote RH. 1999. Fertility of bull sperm frozen and stored in clarified egg yolk-Tris-glycerol extender. J Dairy Sci, 82:817-821.

Watson PF, Martin CA. 1975. The influence of some fractions of egg yolk on the survival of ram spermatozoa at $5^{\circ} \mathrm{C}$. Aust $J$ Biol Sci, 28:145-152. 